\title{
Semi arid browse forages: Their antinutritive substances and in sacco neutral detergent fibre and organic matter degradability
}

\author{
A. A. Njidda ${ }^{1}$ E. A. Olatunji ${ }^{2}$ and A Y. Raji ${ }^{1}$ \\ ${ }^{1}$ Department of Animal Science, Bayero University, Kano, P.M.B. 3011, Kano State, Nigeria \\ ${ }^{2}$ Department of Animal Science, University of Abuja, P.M.B. 117, Abuja, Nigeria.
}

\begin{abstract}
Three ruminally cannulated bulls were used to determine variations in dry matter (DM) degradability of forage consumed by ruminants in the semi-arid region of north Nigeria. Organic matter and crude protein $(C P)$ contents were higher $(P<0.05)$ in all the browse forages. Higher numerical values of neutral detergent fibre $(N D F)$, acid detergent fibre $(A D F)$, lignin and cellulose were recorded. Condensed tannin varied from $0.08 \mathrm{mg} / \mathrm{g}$ DM in Kigalia africana to $0.41 \mathrm{mg} / \mathrm{g}$ DM in Maerua angolensis. A range of 0.24 $\mathrm{mg} / \mathrm{g}$ DM in Olea hochstteteri to $0.48 \mathrm{mg} / \mathrm{g}$ in Khaya senegalensis was obtained for phenolic. Saponin content of the experimental leaves range from $1.08 \mathrm{mg} / \mathrm{g}$ DM in Poupartia sirrea to $2.95 \mathrm{mg} / \mathrm{g}$ DM in Garderna sokotensis. Oxalate in the browses used ranged from $4.59 \mathrm{mg} / \mathrm{g} D M$ in Maerua angolensis to $8.14 \mathrm{mg} / \mathrm{g}$ DM in Olea hochstteteri. The highest value of $5.81 \mathrm{mg} / \mathrm{g} D \mathrm{DM}$ was obtained in Khaya senegalensis while Olea hochstteteri had the lowest value of $2.02 \mathrm{mg} / \mathrm{g}$ DM for Phytic acid in the browses studied. The hydrogen cyanide and Fluoroacetate are generally low in all the browse samples studied. The result showed no significant difference among the browse forages.NDF degradability after 24 and $48 \mathrm{~h}$ of ruminal incubation were higher $(P<0.05)$ in all the browses. Higher values $(P<0.05)$ in DM bag losses at zero time (' $a$ ' fraction) were high for the browses. The insoluble but fermentable NDF (' $b$ ' fractions) were low $(P<0.05)$ among browse forages. Numerically lower values of NDF ' $c$ ' fraction were found in browses except for Kigalia africana, whereas NDF potential degradability were higher $(P<0.05)$ in all the experimental leaves. High $(P<0.05)$ contents of $C P$ in the browse forages, NDF degradability after $48 h$ of ruminal incubation, and $a+b$, were observed in the browse leaves. Thus, these results may be related to both the better feeding value of forage consumed by the animals and better performance of livestock during in these areas. Then, the NDF degradability after 48 h, together with the soluble fraction ' $a$ ' and insoluble but fermentable fraction ' $b$ ' and the $c$ fraction permit the nutritive value of the forage consumed by grazing goats to be accurately described. The rate of OM disappearance was highest for Garderner sokotensis $97.20 \%$ though the values were generally high for all the browse forages studied. The soluble fraction ' $a$ ', rate of degradation ' $c$ ' and effective degradability ' $E D$ ' were generally low for all the browse forages while the insoluble but degradable fraction ' $b$ ' and potential degradability $a+b$ were high for all the browse forages. Base on these findings, it can be concluded that the browse forages are of good nutritive value and can be use as supplement.
\end{abstract}

Keywords: In situ, browse, antinutritive, degradation, neutral detergent fibre, organic matter

\section{Introduction}

Inadequate nutrition due to shortage of feed and year round quality forage is one of the major problems facing ruminant production [1], crop residues or by-products [2] which result in reduced livestock productivity in the tropical countries [3].

Browses are important in providing nutrient to grazing ruminants in arid and semi-arid environments where inadequate feeds are a major constraint for livestock production [4]. Tree fodders maintain higher protein and mineral contents during growth than grasses, which decline rapidly in quality with maturity [1]. Tree fodders are important source of nourishment for grazing ruminants and as supplements to improve the productivity of herbivores fed on low quality feeds. Browse forages form part of the complex interactions between plants, animals and crops [4], the positive aspect of which is to help balance a plant-animal-soil ecosystem from which there is sustainable source of feeds [5]. The availability of a variety of these feeds and the selection process enables the herbivores especially the goats to extend as well as meet their feed preferences. Traditional farmers in the semi-arid region of Nigeria allow their goats, sheep and cattle to browse on tree forages, in the range lands and they also cut and feed these tree foliages as supplements based on experience and convenience. Leguminous trees and shrubs often have thorns, fibrous foliage and growth habits which protect the crown of the tree from defoliation. Many plants also produce chemicals which are not directly involved in the process of plant growth (secondary compound) but act as deterrents to insects and fungal attack. These compounds also affect animals and the nutritive value of the forages. Mycotoxins (fungal metabolites) produced by saprophytic and endophytic fungi are also a potential source of toxins in forages (Norton, 1994). 
The objective of these study is to evaluate the nutritive value of some selected browse forages of semi arid environment using the in sacco technique.

\subsection{Description of site and samples}

\section{Materials And Methods}

All forages were harvested from Gwoza local government area $\left(11.05^{0} \mathrm{~N} ; 30.05^{0} \mathrm{E} ; 364 \mathrm{~m}\right.$ above sea level) of Borno State, North Eastern part of Nigeria. The ambient temperature ranges between 30 and $42^{\circ} \mathrm{C}$ during the hottest period (March to June) and decreases to $19-25^{\circ} \mathrm{C}$ between November and February [6]. Two browse forage species commonly found in the Semi-arid and derived Savannah zones were used in this experiment; the species were Garderna sokotensis, Khaya senegalensis, Kigalia Africana, Leptadenia lancifolia, Maerua angolensis, Olea hochstteteri, and Poupartia sirrea. The browse forages were harvested from at least 10 trees per species selected at random in four locations within the study area at the end of rainy season. The samples were sun-dried, milled and sub- sampled for analysis.

\subsection{Sample preparation}

About $500 \mathrm{~g}$ of the harvested and pooled samples from each plant were oven dried at $105^{\circ} \mathrm{C}$ for 24hours, cooled and weighed. The weight difference between the initial weights and dried weights was taken as the moisture content of the leaves and then converted to percentage. Percent dry matter content was then obtained as the difference between 100 and percent moisture content [7]. The dried weekly samples were then bulked according to plant species and each shared into two portions. One portion was sun dried and milled to pass through $2 \mathrm{~mm}$ sieve, labelled and stored in sealed polythene bags for degradability and in vitro studies. The other portion (also milled to pass through $1 \mathrm{~mm}$ sieve) was labelled and as well stored for proximate analysis.

\subsection{Chemical analysis of browse forages}

The samples were analyzed in triplicate for crude protein (CP), according to AOAC [7] procedures. Neutral detergent fibre (NDF), acid detergent fibre (ADF) and lignin were determined as described in Van Soest et al. [8]. Hemicellulose was estimated as NDF-ADF and cellulose as ADF-lignin. To determine the organic matter content of the residues, sub-samples $(500 \mathrm{mg})$ were placed in crucibles and burnt for 2 hours at $500^{\circ} \mathrm{C}$. The ash was weighed and the value was subtracted from the values for dry matter. The balance sample residues after milling were then used for other chemical analyses. Nitrogen was analyzed according to standard [7] procedure. Crude protein was calculated by multiplying the percent nitrogen content by the factor 6.25 .

\subsection{Anti-Nutritional Factors Assessment in the Samples}

Some anti-nutritional constituents that were determined in the browses include Phytate estimated as phytic acid using the method prescribed by [9], while hydrogencyanide (HCN) was determined by the Knowels and Watkins distillation method as described by Pearson [10]. Saponins and total condensed tannin were determined as reported by Babayemi et al.,[2] and Polshettiwar et al., [11]. Phenolics were determined using Folin Ciocalteu metho as described by Makkar [12].

\subsection{Management and feeding of Animals}

Three ruminally cannulated bulls were used for this experiment. They were housed in individual pens with concrete floors bedded with wood shavings. The beddings were changed weekly. In these pens they were offered corn bran, cowpea husk and salt lick as supplements daily. The animals also had free access to fresh clean water daily. The diet provided the animals were to allow the rumen microbial population meet their requirement for essential nutrients as well as provide optimum rumen environment for degradability. The area around the opening of the cannulae was cleaned regularly with warm water and detergent to prevent infection by pathogens.

\subsection{In sacco NDFand OM degradability study}

The rate of nutrient disappearance in the browse species was determined by the use of nylon bag technique. Milled $(<1.0 \mathrm{~mm})$ samples were oven-dried overnight $(24 \mathrm{hrs})$ at $70^{\circ} \mathrm{C}$ prior to weighing into the bags measuring $140 \times 20 \mathrm{~mm}$ when laid flat. A piece of marble was included in each bag containing $5 \mathrm{~g}$ of feed sample to prevent the bag from floating in the rumen. The weight of each bag and its content was then recorded. Ten bags containing the sample were incubated at the same time in each animal. A bag was removed from each of the three animals at 3, 6, 12, 24, 48, 72 and 96 hours for observation of nutrient disappearance. The experiment was carried out in two periods so that each of the fistulated bulls will have $10 \mathrm{bags} / \mathrm{sample}$. The bags were tied using a nylon twine and carefully inserted into the rumen. After each incubation period, the bags were carefully removed and rinsed with tap water until the water was clean and clear. The washing procedure took $30 \mathrm{~min}$ and then the bags were oven-dried. The bags were allowed to air-calibrate to room temperature for about three hours 
in a desiccator before weighing to determine bag plus marble plus feed sample residue weight for dry matter determination. The difference between the initial and final weights of each sample was regarded as degraded material and thereafter expressed as a percentage of the initial weight. After incubation, all the bags were withdrawn from the rumen at the same time and immediately placed under running cold tap water until the rinse water became clear. This was done to wash off ingested feed particles adhering to the bags as well as stop further fermentative processes. The bags with the sample residues were then oven dried at $65^{\circ} \mathrm{C}$ for 48 hours and the weight of the bags plus residues measured and recorded. The zero-hour washing losses that is, losses due to non-incubation, were determined by soaking $5 \mathrm{~g}$ of each of the samples in triplicates in warm water $\left(37^{\circ} \mathrm{C}\right)$ for 1 hour which was followed by washing and drying of the bags as done with the incubated sample residues. NDF and OM losses was computed as the difference between the determined NDF and OM content of the preincubated samples and the determined NDF and OM content of the incubated residues.

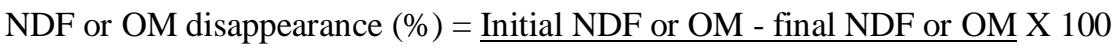 Initial NDF or OM}

Digestion characteristic of NDF and OM were obtained by fitting data to the equation [13]:

$\mathrm{P}=\mathrm{a}+\mathrm{b}(1-\mathrm{e}-\mathrm{ct})$,

Where:

$\mathrm{P}=$ Potential degradability after time ' $\mathrm{t}$ '

$\mathrm{a}=$ Water Soluble Fraction (zero hour)

$\mathrm{b}=$ Insoluble but degradable fraction after time ' $\mathrm{t}$ '

$\mathrm{c}=$ Rate of degradation of slowly degradable fraction $\mathrm{b}$

$\mathrm{t}=$ Incubation length i.e. $3,6,12,24,36,48,72,84$ and 96 hours

$\mathrm{e}=$ exponential

The effective ruminal degradability of NDF (EDNDF) and OM (EDOM) were calculated according to Ørskov and McDonald [14]: EDNDF $=b \times(c /(c+k))$ where $k=0.12 \mathrm{~h}^{-1}$ and EDOM $=(\mathrm{a}+\mathrm{b}) \mathrm{c} /(\mathrm{c}+\mathrm{k})\left(\mathrm{e}^{-(\mathrm{ct}) \mathrm{LT}}\right)$ where $k=0.12 \mathrm{~h}^{-1}$

\subsection{Statistical Analysis}

Data obtained from the degradation characteristic of the incubated plant species at the different hours were subjected to analysis of variance [15] using the completely randomized design. Treatment means were separated by Duncan's multiple range test.

\subsection{Chemical composition of the browse forages}

\section{Results}

The proximate composition of the browse forage leaves determined in this study is presented in Table 1. Dry matter content ranged from $838.30 \mathrm{~g} \mathrm{~kg}^{-1} \mathrm{DM}$ in Poupartia sirrea to $983.00 \mathrm{~g} \mathrm{~kg}^{-1}$ in Garderna sokotensis on DM basis. Generally, the examined plant leaves had high crude protein values. The mean content of this nutrient was $147.64 \%$ ranging from $132.20 \mathrm{~g} \mathrm{~kg}^{-1} \mathrm{DM}$ in Poupartia sirrea to $174.30 \mathrm{~g} \mathrm{~kg}^{-1} \mathrm{DM}$ in Maerua angolensis. Values obtained for organic matter content of the browse forages ranged from $742.60 \%$ in Poupartia sirrea to $868.70 \mathrm{~g} \mathrm{~kg}^{-1} \mathrm{DM}$ in Khaya senegalensis.

\subsection{Fibre content of semi-arid browse forages}

The highest neutral detergent fibre content of $688.10 \mathrm{~g} \mathrm{~kg}^{-1} \mathrm{DM}$ was recorded in Kigalia africana while Leptadenia lancifonia had the lowest value of $433.10 \mathrm{~g} \mathrm{~kg}^{-1} \mathrm{DM}$. The acid detergent fibre levels in the experimental leaves ranged from $206.80 \mathrm{~g} \mathrm{~kg}^{-1} \mathrm{DM}$ in Olea hochstteteri to $255.20 \mathrm{~g} \mathrm{~kg}^{-1} \mathrm{DM}$ in Kigalia afrcana. The least lignin content of $96.70 \mathrm{~g} \mathrm{~kg}^{-1} \mathrm{DM}$ in the browse forages was recorded in Olea hochstteteri while Leptadenia lancifonia had the highest value of $152.80 \mathrm{~g} \mathrm{~kg}^{-1} \mathrm{DM}$. Cellulose levels in the browse forages were within the range of $131.20 \mathrm{~g} \mathrm{~kg}^{-1} \mathrm{DM}$ in Leptadenia lancifolia to $183.20 \mathrm{~g} \mathrm{~kg}^{-1} \mathrm{DM}$ in Garderna sokotensis while hemicellulose content of the browse leaves ranged from $189.20 \mathrm{~g} \mathrm{~kg}^{-1} \mathrm{DM}$ in Leptadenia lancifonia to $432.90 \mathrm{~g} \mathrm{~kg}^{-1} \mathrm{DM}$ in Kigalia africana.

\subsection{Anti-nutritional factor levels of semi-arid browse forages}

The result of anti-nutritional constituents in the browse forage leaves is shown in Table 2. Total condensed tannin varied from $0.08 \mathrm{mg} / \mathrm{g}$ DM in Kigalia africana to $0.41 \mathrm{mg} / \mathrm{g}$ DM in Maerua angolensis. A range of $0.24 \mathrm{mg} / \mathrm{g}$ DM in Olea hochstteteri to $0.48 \mathrm{mg} / \mathrm{g}$ in Khaya senegalensis was obtained for phenolic. Saponin content of the experimental leaves range from $1.08 \mathrm{mg} / \mathrm{g}$ DM in Poupartia sirrea to $2.95 \mathrm{mg} / \mathrm{g} \mathrm{DM}$ in Garderna sokotensis. Oxalate in the browses used ranged from $4.59 \mathrm{mg} / \mathrm{g}$ DM in Maerua angolensis to 8.14 $\mathrm{mg} / \mathrm{g}$ DM in Olea hochstteteri. The highest value of $5.81 \mathrm{mg} / \mathrm{g}$ DM was obtained in Khaya senegalensis while 
Olea hochstteteri had the lowest value of $2.02 \mathrm{mg} / \mathrm{g}$ DM for Phytic acid in the browses studied. The hydrogen cyanide and Fluoroacetate are generally low in all the browse samples studied. The result showed no significant difference among the browse forages.

\subsection{Neutral detergent fibre (NDF) disappearance}

The NDF disappearance of the browse forages analysed is shown in Figure 1. An initial high rate in disappearance of NDF from the incubated leaves was observed at $3 \mathrm{hr}$ with none of the leaves noticed to have lost less than 34\% of its NDF content. However the trend of NDF disappearance in all the browse forages was slow from 3 to 96 hrs of incubation with all the browse forages having more thane $60 \%$ of their NDF content degraded by 96 hrs of incubation except for Olea hochstteteri having 59.31\%. NDF in Garderna sokotensis (70.59\%), Kigalia africana (73.85\%) and Poupartia sirrea (71.09\%) were highly soluble and $96 \mathrm{hrs}$ of incubation periods.

\subsection{Organic Matter (OM) disappearance}

The extent of disappearance of OM in the incubated browse leaves is shown in Figure 2. Organic matter content was highly degradable though it progressed slowly from 0 hour to 96 hours. The OM disappearance were generally low for all the browse forages at $0-24$ hours incubation periods. Garderna sokotensis had the highest OM disappearance of $97.20 \%$

\subsection{Neutral detergent fibre (NDF) fermentation characteristics}

The degradation characteristics for NDF in the browse leaves incubated in the rumen of bulls are as shown in Table 2 . The means for the various characteristics measured varied significantly $(\mathrm{P}<0.05)$. The rapidly degradable fraction 'a' in the NDF component of the browse tested ranged from $35.93 \%$ in Olea hochstteteri to $62.20 \%$ in Kigalia africana. Results reported for the insoluble but degradable fraction ' $b$ ' in the NDF content was low ranging between $12.46 \%$ and $24.91 \%$ in Maerua angolensis and Olea hochstteteri respectively. Potential degradation ' $a+b$ ' values obtained for NDF in the leaves studied was from $60.84 \%$ in Olea hochstteteri to $75.06 \%$ in Kigalia africana. The degradation rate c" of NDF in the leaves was observed lowest in Garderna sokotensis with a value of $0.027 / \mathrm{hr}$ and highest in Kigalia africana with a value of $1.035 / \mathrm{hr}$. Effective degradability (ED) (0.12) estimates for NDF were observed to be generally fair in the leaves used for this study.

\subsection{Organic matter $(O M)$ fermentation characteristics}

Organic matter degradation characteristics for the incubated browse leaves are shown in Table 3. Except for rate of degradation ' $c$ ' which was not significant, all other characteristics varied significantly $(\mathrm{P}<0.05)$. Values obtained for the solubility of $\mathrm{OM}$ in browse leaves ranged from a low value of $2.23 \%$ in Maerua angolensis to a high value of $8.76 \%$ in Garderna sokotensis. With the insoluble but degradable fraction ' $\mathrm{b}$ ', OM recorded the least value in Maerua angolensis (59.24\%) while the highest was in Poupatia sirrea with $73.16 \%$. No significant differences $(\mathrm{P}>0.05)$ were observed for degradation rate constant between the leaves studied. However, a range of $0.017 / \mathrm{hr}$ in Poupatia sirrea to $0.060 / \mathrm{hr}$ in Maerua angolensis was observed. At an outflow rate of 0.12, the effective degradability of OM was highest in Garderna sokotensis (20.70\%) and lowest in Poupartia sirrea (12.30\%).

\section{Discussion}

\subsection{Chemical composition of selected browes forages of semi-arid}

The crude protein (CP) content of the browse forages studied was generally higher, which is above the $7 \% \mathrm{CP}$ requirement for ruminants that should provide ammonia required by rumen microorganism to support optimum microbial growth. The high CP content of browse species is well documented and is one of the main distinctive characteristic of browse compared to most grasses. [16] reported a range of $\mathrm{CP}$ contents from 12 to $30 \%$ for tropical tree legumes, and [17] gave a mean of 12.5\% in West African browse species with about 17\% for leguminous species. Generally, the CP content in browse has been shown to be above the minimum level required (7\%) for microbial activities in the rumen [16].

With regard to the fibre content, Rittner and Reed [18] reported similar mean for NDF and lignin contents across different ecological zones as follows $40.1 \%$ and $11.7 \%$ in the Sahelian zone, $45.7 \%$ and $10.5 \%$ in the sub-humid zone and $43.6 \%$ and $9.3 \%$ in the humid zone respectively. NDF and ADF contents in the browse forages studied were similar to the values reported by Njidda [19] and this can limit feed intake [20]. This species also had a high lignin content. Lignin is a component of the cell wall, and deposited as part of the cell wall-thickening process [21]. Lignin is in general higher in browse than in herbaceous plants. The content varies according to species, age and the plant parts. Positive correlations were reported between contents of lignin and soluble or insoluble proanthocyanidins [18]. 
Cellulose is closely associated with lignin thus the observed relatively high lignin content in the examined plant leaves may have resulted in the high cellulose levels in this study. In other words, the concentration of cellulose provides an insight as to the level to which the forage has been lignified. The high level of lignin in the studied leaves could be adduced to their maturation. This is likely so because according to Wilson [22] environmental factors, particularly temperature, significantly influence the content and digestibility of cell wall in forage through faster tissue maturation.

The cell wall content hemicellulose was observed to be fairly high. With a mean value of $310.27 \mathrm{~g} \mathrm{~kg}^{-1}$ DM in the investigated plants, they appeared quite high compared to reported levels in the common browse forages. These hemicelluloses levels in the plants may be acceptable levels although rumen microbes are incapable of adequately degrading this fibre component of plants. Going by the observations of Roger et al. [23] and Njidda [18] who noted that sundrying affected the chemical composition of tree legumes, the high hemicellulose content of the leaves in this study may have probably been due to the drying of samples of the plants before they were analysed.

\subsection{Anti-nutritive substances}

Tannins are phenolic plant secondary compounds and are widely distributed through the plant kingdom, especially legumes and browses which affect animal performance in many countries [24]. The level of $\mathrm{CT}$ is lower than the range of 60 to $100 \mathrm{~g} \mathrm{Kg}^{-1} \mathrm{DM}$ considered to depress feed intake and growth [25] but within the range 0.41 to $0.81 \mathrm{mg} \mathrm{g}^{-1}$ DM reported by Njidda et al. [26] for semi arid browse forages. Feeding tannin containing plant can decrease ruminal protein degradation, promote microbial crude protein (CP) synthesis [27], and prevent excessive ruminal gas formation which can lead to bloat [28, 29]. However, in ruminants, dietary condensed tannins of 2 to $3 \%$ have been shown to have beneficial effects because they reduce the protein degradation in the rumen by the formation of a protein-tannin complex [30, 31] and increasing absorption of amino acids in the small intestine [32]. On this basis, they have been proposed as feed additives to improve digestive utilisation of dietary protein [33]. While moderate concentrations of CT (2-4.5\% DM) can exert beneficial effects on protein metabolism in ruminants, high dietary CT concentrations (>5.5\% DM) can depress voluntary feed intake, digestive efficiency and animal productivity. However, effects are not the same for all CT as they depend upon its chemical structure [24]. Several ruminal microorganisms have been identified that can tolerat relatively high concentrations of both hydrolysable and condensed tannins (CTs) [34]. However, the mechanism for this tolerance has not been completely elucidated. The values for phenolic compounds in this study were lower compared to that reported by Osuga et al. [35]. Phenolic compounds are the largest single group of secondary plant compounds (SPCs), and total phenolics in plants can reach up to $40 \%$ of the dry matter [36]. In grasses, the major phenolic is lignin that is bound to all plant cell walls, and is a significant limiting factor in their digestion in the rumen [34]. Lignin is also a limiting factor in the digestion of legumes, but is bound largely to the vascular tissue [38], with often high concentrations of other free and bound phenolic compounds (phenolic acids, coumarins and flavonoids) in floral, leaf and seed tissues [39].

Oxalate content in this present study was low. It has been reported that $20 \mathrm{~g} / \mathrm{kg}$ oxalate can be lethal to chicken [40]. Oxalate has been shown to deplete the calcium reserve, but these browse species were found to contain reasonable amount of calcium, magnesium and phosphorus. Ca and carbon are also released from the hydrolysis of $\mathrm{Ca}$ Oxalate some of which will be either absorbed or excreted by the ruminant animals. With $\mathrm{Ca}$ absorption rate of ruminants put at 31\% [41] and $\mathrm{P}$ at $4 \%$ absorption [42] reasonable amount of the $\mathrm{Ca}$ and $\mathrm{P}$ intakes will be lost via faeces and urine to the soil. Such voided minerals/nutrients are thereby recycled for further use to support plants which are ploughed back into the soil. When so much $\mathrm{N}$ is returned to the soil, this reduces the use of inorganic $\mathrm{N}$ fertilizer and lends weight to the use of organic manure in farming. However, given the time to adapt, the microorganisms in the rumen can metabolise moderate amounts of oxalate.

Saponins are group of compounds containing an a-glycone moiety linked to carbohydrates. Many plant species consumed by livestock contain saponins. Feedstuffs containing saponin have been shown to be defaunating agents [43] and capable of reducing methane production [44]. Saponins have effect on erythrocyte haemolysis, reduction of blood and liver cholesterol, depression of growth rate, bloat (ruminant), inhibition of smooth muscle activity, enzyme inhibition and reduction in nutrient absorption [45]. Saponins have been reported to alter cell wall permeability and therefore to produce some toxic effects when ingested [46]. The antinutritional effects of saponins have been mainly studied using alfalfa saponins. Sharma and Chandra [47] observed that 4-7 weeks of ad libitum feeding of albizia gave rise to toxic manifestation in sheep. Symptoms include listlessness, anorexia, weight loss and gastro-enteritis. The toxicity of saponins can be reduced by repeatedly soaking the feed in water. The level recorded in this present study may not pose any problem the animals.

Phytic acid is a phosphoric acid derivative of myo-inositol. It constitutes an important component of forage plants with the ability to chelate essential minerals including calcium, magnesium, iron, zinc and molybdenum[42]. The resulting chelates resist breakdown in the digestive tract and become unavailable thus 
inducing dietary deficiency of these elements [42]. Most of the phosphorus in plants is organically bound to phytic acid [9]. In this regard, it was reported that $40-50 \%$ and $28 \%$ respectively of the total phosphorus are present as phytate-phosphorus, which is unavailable for utilization by animals [48]. However, [42] noted that a phytic acid degrading enzyme phytase appears to be present in the gastrointestinal tract. This is possibly why phytic acid bound phosphorus can be utilized to some extent by ruminants [49]. The phytin levels reported in this study is lower than 13.80 to $25.20 \mathrm{mg} / \mathrm{g}$ DM reported by Okoli et al. [50] for the southeastern browses in Nigeria. These levels are unlikely to have any adverse effects on ruminants.

The HCN contents of the browse species examined were equally low. The lethal dose of $\mathrm{HCN}$ for cattle and sheep is 2.0 to $4.0 \mathrm{mg}$ per $\mathrm{kg}$ body weight. The lethal dose for cyanogens would be 10 to 20 times greater because the $\mathrm{HCN}$ comprised 5 to $10 \%$ of their molecular weight [51]. However, the quantity of HCN produced by most of these species is too low to pose major animal health problems [52]. Animals suffering from cyanide toxicity must be immediately treated by injecting a suitable dose of sodium nitrate and sodium thiosulphate [53]. Generally, only plants that produce more than $20 \mathrm{mg} \mathrm{HCN} / 100 \mathrm{~g}$ fresh weight are considered deleterious [54]. The value for fluoroacetate was negligible to pose any problem to animals although if the compound is in large amounts it is known to inhibit the Krebs cycle by formation of fluoroacetate [55] and is used as a poison for rats and rabbits [56].

Fibre digestion in the rumen is a function of both the rate of degradation as well is the retention time in the rumen [57]. Furthermore, [58] is of the view that fibre degradation in the rumen is positively related to dry matter intake by ruminant.

The degradation parameters of neutral detergent fibre varied between the plant leaves studied. This corroborates the assertion by Yang [59] that species of forage influence neutral detergent fibre degradation characteristics. The variation in the soluble fraction in which Faidhebia albida was observed to have the highest value, may have resulted from variation in the degree of lignifications. Negative effect of cell wall on digestibility has been earlier reported [60]. This result was similar to what [61] reported for the neutral detergent fibre in some multipurpose trees but higher than what [62] reported for oil palm fronds. All the leaves tested revealed relatively low levels of insoluble but degradable fraction of neutral detergent fibre. These figures were lower than the range of 40-56.3\% reported for some browse species [63]. The rate of degradation 'c' of neutral detergent fibre in the leaves were generally low except for Kigalia africana. This is likely to result in rumen fill and by extension reduce intake. Decreased rumen $\mathrm{pH}$ to affect rate of degradation in vitro [64] and in vivo [63] although this factor was not measured in this study. These low degradation rates of neutral detergent fibre degradation in the leaves may have been influenced by the long time it took the microbes to initiate cell wall degradation (lag time) of this nutrient. The neutral detergent fibre degradation rates in these leaves were lower than values reported by Moya-Rodrigucz et al. [63] for tropical browse species, Kigalia africana had the highest potentially degradable neutral detergent fibre value in this study. This may have derived from the high level of insoluble fraction. Hindrichsen et al.[61] however reported higher values for this parameter than was observed with the leaves of this study. Effectively and although moderately high in the leaves investigated, NDF in the browse forage leaves were better degraded than the others. This may have arisen from the high level of the soluble fraction in of the browse forages. Effective degradability of neutral detergent fibre in the leaves studied was observed lower than ealier reported values [61,63].

Recorded values for fibre component disappearance from the studied leaves were generally high. These loss of neutral detergent fibre from the experiment leaves was slow such that during $48 \mathrm{hrs}$ incubation the highest value was $73.59 \%$ (Kigalia africana). This slow trend continued up till 96hrs of incubation. This may have resulted due to the slow rate of degradation 'c' of this nutrient. This view is supported by the observation of Archimede et al. [65] that microbial digestion of fibre in the rumen is reduced when retention time of digesta in the rumen decreases. It is also thought that rumen $\mathrm{pH}$ may have been acidic. By the end of 96hrs incubation all the incubated browse leaves had more than $60 \%$ of their neutral detergent fibre content degraded except for Olea hochstteteri $59.31 \%$. Disappearance values for this fibre component was least in Olea hochstteteri during $48 \mathrm{hrs}(56.91 \%)$ and $96 \mathrm{hrs}(59.31 \%)$ incubation periods.

Determining the degradation of organic matter in situ is essential. This is in view of the fact that microbial protein synthesis is highly dependent on availability of rumen degradable organic matter $[66,67]$ are of the view that rate of nitrogen and carbohydrate degradation especially from forage and concentrate mixtures, increase the efficiency of microbial protein synthesis due to improved rumen environment for the growth of more diverse bacteria species. The shrub and tree leaves used in this study varied in organic matter degradation characteristics,

Readily soluble fraction of organic matter in the test leaves was observed to be highest $18.76 \%$ in both Gardena sokotensis. This may be due to the presence of degradable carbohydrates, particularly the non-structural ones and NDF proteins and fat, components that may make organic matter readily degradable in situ in the rumen [68]. In this regard, NRC [69]) suggests that feeding diets with at least $12 \%$ protein may be necessary to maximize organic matter fermentation in the rumen. On the contrary the least 'a' value recorded in Maerua 
angolensis indicates that this browse forage may be composed of slow degrading carbohydrates, likely to affect the efficiency of microbial protein synthesis [70]. Nevertheless, the organic matter solubility range reported in the shrub and tree leaves of this of this study (2.23 to 8.76\%) were higher than values reported in some roughages [68]. The insoluble but degradable organic matter frraction ' $b$ ' was high in the plant leaves compared to values reported for some multipurpose tree species [71]. This may be the result of the organic matter solubility in the leaves indicating the possibility of a high amount of nutrients by-passing the rumen microbes. The potential degradability ' $a+b$ ' of the organic matter in the leaves studied was generally high and reflected the high soluble ('a') organic matter fraction in the leaves. This may have been due to the low rate of degradation constant 'c' as inferred by Kibon and Ørskov [72] with the potential degradability of dry matter in browse plants. Potential degradability values reported for roughages [68] were similar to what obtained in this investigation. Effective degradability values reported for organic matter in-the leaves studied showed this nutrient to be well degraded in situ at an outflow value of 0.12 . However, [73] have observed variations in effective degradability amongst leaves to be associated with variability within the leaves.

\section{Conclusion}

In conclusion, the leaves of the browse forages showed high potential as a feed supplement to ruminant animal in the semi arid especially in terms of crude protein supply for effective microbial activity in the rumen.

\section{References}

[1] Shelton, H.M. (2004). The importance of silvopastroal systems in rural livelihoods to provide ecosystem services. Proc. Of the $12^{\text {th }}$ International Symposium on Silvopastoal Systems. In: 't. Marnietje, L., Ramirez, L., Ibrahim, M, Sandoval, C. Ojeda, N and Ku, J. (eds). Universidad Antronoma de Yucatan, Merida, Yucatan, Mexico, 2004. pp. 158-174.

[2] Babayemi, O. J., D. Demeyer, and V. Fieves (2004). Nutritional value of qualitative assessment of secondary compound in seeds of eight tropical browse, shrub and pulse legumes. Communication in Applied Biological Science. Ghent University, 69/1: 103-110.

[3] Odenyo, A. A., Osuji, P. O., Karanfil, O. and Adinew, K. (1997). Microbiological evaluation of Acacia angustissima as a protein upplement for sheep. Anim. Feed Sci. Tech. 65: 99-112.

[4] Aganga, A. A. and Tshwenyane, S.O. (2003). Feeding values and Anti-nutritive factors of forage tree legumes. Pakistan Journal Nutrition 2 (3): 170-177

[5] Devendra, C. (1994). Composition and nutritive value of browse legumes, pp. In: Forage tree legumes in tropical agricultures 4965.

[6] Alaku, S.O. and Moruppa, S. M. (1988). Organ weight losses in goat during the long dry season in the sahel region of west Africa. Journal Arid Agriculture 1:23-35.

[7] AOAC (2002). Official Methods of Analysis of Official Analytical Chemists (W. Horwtz ed.) $17^{\text {th }}$ Edition, Association of Analytical Chemists, Washington. DC.

[8] Van Soest, P. J., Robertson, J. B. and Lewis, B. (1991). Methods for dietary fibre, neutral detergent fibre, and nonstarch polysaccharides in relation to animal nutrition. Journal Dairy Scieince 74, 3583-3597.

[9] Maga, J. A. (1982). Phytate, its chemistry, occurrence, food interaction, nutritional significance and methods of analysis. Journal of Agriculture and Food chemistry. 30: 1-5

[10] Pearson, D. (1976). The chemical analysis of foods. Churchill Livingston, Edinburgh. Pp. 352-354.

[11] Polshettiwar, S. A., Ganjiwale, R.O., Wadher, S. J. and Yeole, P.G. (2007). Spectrophotometric estimation of total tannins in some ayurvedic eye drops. Indian Journal Pharmaceutical Science 69 (4):574-576.

[12] Makkar, H. P. S. (2000). Quantification of tannins in tree foliage-a laboratory manual; a joint FAO/IAEA working document, Vienna, Austria.

[13] Ørskov, E. R. and Shand, (1997). Use of the nylon bag technique for protein and energy evaluation and for rumen environment studies in ruminants. Livestock Research for Rural Development, 9:1-10, http://www.cipav.org.co/lrrd/lrrd9/1/orskov.htm.

[14] Ørskov, E. R. and McDonald, I. (1979). The estimation of protein degradability in the rumen from incubation measurements weighted according to rate of passage. Journal Agricultural Science (Cambridge) 92: 499-503.

[15] Gomez, K. A. and Gomez, A. A. (1984). Statistical Procedures for Agricultural Research. (2 ${ }^{\text {ND }}$ ed.). John Wiley and Sons, New York, USA. 680pp.

[16] Norton, B.W. (1998). The nutritive value of tree legumes. In: Gutteridge, R.C., Shelton, H.M. (Eds.), Forage trees legumes in Tropical Agriculture. Tropical Grassland Society of Australia Inc., St Lucia Queensland.

[17] Le Houerou, H.N. (1980) Chemical composition and nutritive value of browse in West Africa. In: Le Houerou, H.N. (ed.), Browse in Africa. ILCA, Addis Ababa, Ethiopia, pp. 261-290.

[18] Rittner, U. and Reed, J. D. (1992). Phenolics and in vitro degradability of protein and fiber in West African browse. Journal of the Science of Food and Agriculture 58, 21-28.

[19] Njidda, A A. (2011). Evaluation of the potential nutritive value of browse forages of semi- arid region of Nigeria. Ph D Thesis submitted to the Department of Animal Science, Ambrose Alli University,Ekpoma Nigeria. 219pp

[20] Meissner, H. H., Viljoen, M. D. and Van Nierkeki, W. A. (1991). Intake and digestibility by sheep of Anthephora, Panicum, Rhode and Smuts finger grass pastures: Proceeding of the IVth International Rangeland Congress, September1991. Montipellier, France, pp 648-649.

[21] Boudet, A.M. (1998). A new view of lignification. Trends in Plant Science, 3, 67-71.

[22] Wilson, T. (1982). Husbandary, nutrition and productivity of goats and sheep in tropical Africa. Proceedings of a Seminar held at the International livestock Centre for Africa, Addis Ababa, Ethiopia. Pp 61-67.

[23] Roger, C. M., Pond, K. R., Burns, J. C. and Fisher, D. S. (1996). Condensed tannins in Calliandra calothysus and their effects on feeding value. In: Proceedings of a Workshorp on Forest, Farm and Community Tree Research Reports (Special Issue). 23-27 January 1996. Winrock International, Morrilton, Arkansas, USA. Pp 222-233.

[24] Min, B.R., Barry, T.N., Attwood, G.T. and McNabb, W.C. (2003).The effect of condensed tannins on the nutrition and health of ruminants fed fresh temperate forages: a review Animal Feed Science and Technology 106: 3-19 
[25] Barry, T. N. and Duncan, S. J. (1984). The role of condensed tannins in the nutritional value of Lotus pedunculatus for sheep. 1. Voluntary intake. Journal Association Official Analytical Chemist 65: 496-497.

[26] Njidda, A. A., Ikhimioya, I. and Aliyu, I. (2008). Nutritive evaluation of some browsable trees and shrubs leaves from semi-arid region of Nigeria. Journal Arid Agricultural 18: 21-27.

[27] Cardozo, P.W., Calsamiglia, S., Ferret, A. and \& Kamel, C., (2004). Effects of natural plant extracts on ruminal protein degradation and fermentation profiles in continuous culture. Journal of Animal Science 82, 2336-3230.

[28] Waghorn, G.C., (2003). Consequences of plant phenolic compounds for productivity and health of ruminants. Proceeding of Nutrition Soceity 62, 383-392.

[29] Wina, E., Muetzel, S., Hoffmann, E.M. and Becker, K., (2004). Effects of saponin-containing methanol extract of Sapindus rarak on ruminal flora and fermentation characteristics in vivo. Reproduction, Nutrition and Development 44, S41.

[30] Barry, H. J. (1987). Secondary compounds of forages. In: Nutrition of herbivores. Hacker, J.B. and Ternouth, J. H. (eds) A. P. Sydney pp. $91-120$

[31] Njidda, A. A. Ikhimioya, I. Abbator, F. I. and Ngoshe, A. A. (2009).Nutritional effects of Tannins in Animal nutrition: A Review. In: B.I. Umoh, A. B. I. Udedibie, I. P. Solomon, O. L. Obasi, B. I. Okon and E. J. Udoh (eds).Proc. of $34^{\text {th }}$ Ann. Conf. of Nig. Soc. For Animal Prod.(NSAP) $15^{\text {th }}-18^{\text {th }}$ March, 2009. University of Uyo, Uyo, Akwa Ibom State, Nigeria. Pp $629-632$.

[32] Barry, T. N. and McNabb, W. C. (1999). The implications of condensed tannins on the nutritive value of temperate forages fed to ruminants. British Journal Nutrition 81: 263-272

[33] Schwab, C. G. (1995). Protected proteins and amino acids for ruminants. In: Wallace, R. J., Chesson, A. (Eds.), Biotechnology in Animal Feeds and Animal Feeding. VCH Press, Weinhein, Germany, pp. 115-141.

[34] O'Donovan, L. and Brooker, J. D. (2001). Effect of hydrolysable and condensed tannins on growth, morphology and metabolism of ruminants Streptococcus gallolyticus (S. caprinus) and Streptococcus bovis. Microbiology 147, 1025-1033.

[35] Osuga, I. M., Abdulrazak, S. A., Nishino, N., Ichinohe, T. and Fujihara, T. (2006b). Potential nutritive value of selected browse species from Kenya using in vitro gas production technique and polyethylene glycol. Livestock Research Rural Development. 18, Article \#171. http://www.lrrd.org//rrd18/12/osug18171.htm

[36] Tanner, J. C., Reed, J. D. and Owen, E. (1990). The nutritive value of fruits (pods with seeds) from four Acacia Specie compared with nong (Guizolia abyssinica) meal as supplements to maize stover for Ethiopian high land sheep. Animal Production 51: 127133.

[37] Minson, D.J., (1990). Forage I ruminant nutrition. Academic Press Inc., London, UK., 483.

[38] Wilson, J. R. (1993) Organization of forage plant tissues. In: Forage Cell Wall Structure and Digestibility (Jung, H. G., Buxton, D. R., Hatfield, R. D. and Ralph, J., eds.), pp. 1-32. American Society of Agronomy, Madison, WI.

[39] McLeod, M.N. (1974). Plant tannins: Their Role in Forage Quality. Nut. Abstr. Rev. 11: 803-815

[40] Acamovic, T., Steward, C.S. and Pennycott, T.W. (eds) (2004). Poisonous plants and related toxins. Oxford University Press, $608 \mathrm{pp}$

[41] Haenlein, G.F.W. (1987). Mineral and vitamin requirements and deficiencies. $4^{\text {th }}$ International conference on goat of the International Goat Association (IGA) Brasila, Brazile, March 8-13, 1987, Pp 1249-1266.

[42] Iqbal, M. U., Bilal, Q., Muhammad, G. and Sajid, M. S. (2005). Absorption, Availabilty, Metabolism and Excretion of Phosphorus in ruminants. A Review. International Journal of Agriculture and Biology 7 (4): 689-693

[43] Teferedegne, B. (2000). New perspectives on the use of tropical plants to improve ruminant nutrition. Proceeding of Nutrition Soceity 59: 209-214.

[44] Hu, W.,Wu, Y., Liu, J., Guo, Y. and Ye, W. (2005). Tea saponins affect in vitro fermentation and methanogenesis in faunated and defaunated rumen fluid. Journal Zhejiang Universal Science. B 6, 787-792.

[45] Cheeke, P. R. (1971). Nutritional and Physiological implication Saponins: A Review. Canadian Journal Animal Science 51: 621623

[46] Belmar, R., Nava-Montero, R. Sandoval-Castro, C. and Menab, J.M. (1999). Jackbean (canuvalia ensiforms L. DC) in poultry diets: Anti-nutritional factors and detoxification studies. A. Review. Poultry Science Journal 55 (1) 37-59.

[47] Sharma, D. D. S, Chandra, and Negi, S. S. (1969). The nutritive value and toxicity of OHI (Albizia stipulate Bovin) tree leaves. Journal of Research in Ludlhiana 6: 388-393.

[48] Deka, R. K. and Sarkar, C. R. (1990). Nutrient composition and anti-nutritional factors of Dolichos lablab L. seeds. Food Chemistry,38: 239-246.

[49] McDonald, P., Edwards, R. A. and Green Halgh. (1988). Animal Nutrition, Longman Scientific and Technical, Essex, England. Pp. 543.

[50] Okoli, I.C., Ebere, C.S., Uchegbu, M.C., Udah, C.A. and Ibeawuchi, I.I. (2003). A survey of the diversity of plants utilized for small ruminant feeding in south-eastern Nigeria. Agriculture, Ecosystems and Environment 96, 147-154.

[51] Conn, E. E. (1979). Cynamide and cynogenic glycosides in herbivores, their interaction with secondary plant metabolites. Rosenthal, G.A. Jansen, D.H. (eds) A. P., New York pp. 387-412.

[52] Kumar, R. and D’Mello, J. P. F. (1998). Anti-nutritional factors in forage legumes. In: tropical legumes in animal nutrition D'Mello J. P. F. and Devendra, D. (eds) CAB International Wallingford UK.

[53] Kumar, R. (2003). Anti-nutritive factors, the potential risks oftoxicity and methods to alleviate them. http://www.faop.org/DOCREP/003/TO632E/T0632E10.htm

[54] Everist, S. L (1981). Poisonous plants of Australia. Revised edition. Angus and Robertson, Sydney.

[55] Everist, S.L. (1974). Poisonous plants in Australia. Angus and Robertson, Sydney, 684pp.

[56] Norton, B.W. (1994a). Anti-nutritive and toxic factors in forage tree legumes pp. 202-215. In Gutteridge R. C. and H.M. Shelton.

[57] Dorshort, M.E. and Grummer, R. R (2002). Effects of day relative to parturition and dietary crude protein on rumen fermentation in pre-partum transition cows. Journal of Dairy Science 85: 2290-2298.

[58] Mertens, D. R. (1987). Predicting intake and digestibility using mathematical models of ruminal function. Journal of Animal Science 64: 1548-1560.

[59] Yang, C. M. J (2002). Response of forage fibre degradation by ruminal microorganisms to branched-chain volatile fatty acids, amino acids and dipeptides. Journal of Dairy Science 85: 1183-1190.

[60] Njidda, A A. and I. Ikhimioya (2010). Correlation between chemical composition and in vitro dry matter of leaves of semi-arid browses of North-eastern Nigeria. American-Eurasian J. Agric. And Environ. Sci., 9 (2): 169-175.

[61] Hindrichsen, I. K., Osuji, P. O., Odenyo, A. A., Madsen, J. and Hvelplund, T. (2001). Effects of supplementation with four multipurpose trees and Lablab purpureus on rumen microbial population, rumen fermentation, digesta kinetics and microbial protein supply of sheep fed maize stover ad libitum. In: Proceedings of Tanzanian Society of Animal Production Science Conference, Morogoro, Tanzania. 7-10 August 2001. Vol. 28. 14pp. 
[62] Khamseekhiew, B., Liang, J. B., Jelan, Z. A. and Wong, C. C. (2002). Fibre degradability of oil palm frond pellet, supplemented with Arachis pintol in cattle. Songklanakarin Journal of Science and Technology 24(2): 209-216.

[63] Moya-Rodriguez, J.G, Ramirez, R.G \& Foroughbakhch, R (2002). Seasonal changes in cell digeston of eight brwose species from northeastern Mexico.livestock Resaerch for rural development, (14) 1. 6pp http://www.cipvag.org.co/lrrd/lrrd14/1/moya141.htm

[64] Grant, R. J. and Mertens, D. R. (1992). Influence of buffer $\mathrm{pH}$ and raw corn starch addition on in vitro fibre digestion kinetics. Journal of Dairy Science 44:2762-2768.

[65] Archimedes, H., Sauvant, D. and Schmidely, P. (1997). Quantitative review of ruminal and total tract digestion of mixed diet organic matter and carbohydrates. Reproduction, Nutrition and Development., 37: 173-189.

[66] Clark, J.H Klusmeyer, T.H and Cameron, M.R (1992). Microbial protein synthesis and flows of nitrogen fractions to the duodenum of dairy cows. Journal of Diary science, 75: 2304-2323.

[67] Karshi, M. A. and Russell, J. B. (2001). Effects of some dietary factors on ruminal microbial protein synthesis. Turkish Journal of Veterinary and Animal Science 25: 681-686.

[68] Arieli, A., Mabjeesh, S.J., Shabi, Z., Bruckental, L, Aharoni, Y., Zamwel, S. and Tagari, H. (1998). In situ assessment of degradability of organic matter in the rumen of dairy cows. Journal Dairy Science 81: 1985-1990.

[69] NRC, (2001). Nutrient Requirements of Dairy Cattle. National Academy Press, Washington, DC, USA, 381 pp.

[70] Beever, D.E. and Cottril, B.R. (1994). Protein systems for feeding ruminant livestock: a European assessment. Journal of Dairy science, 77:2031-2043.

[71] Arigbede, O.M., Bamikole, M.A., Olanite, J.A., Jalaosho, A.O. and Onifade, O.S.(2002). Seasonal degradability of dry matter, organic matter and crude protein in some multipurpose tree species by West African Dwarf goats. In: Proceedings of the 27' Annual Conference of the Nigerian Society for Animal Production, March 17-21, Federal University of Technology, Akure, Nigeria. Pp 191-194.

[72] Kibon, A and Ørskov, E.R (1993). The use of degradation characteristic of browse plants to predict intake and digestibility of goats. Animal Production 57: 247-251

[73] Nocek, J.E and Russell J.B (1988). Protein and energy as an integrated system: relationship of ruminal protein and carbohydrates availability to microbial: synthesis and milk production. Journal of Dairy Science 71:207-210

Table 1. Chemical composition of browse forages of Semi-arid region of Nigeria $\left(\mathrm{g} \mathrm{kg}^{-1} \mathrm{DM}\right)$.

\begin{tabular}{lccllllll}
\hline Browse Forages & DM & CP & NDF & ADF & ADL & Cell & HC & OM \\
\hline Garderna sokotensis & $983.00^{\mathrm{a}}$ & $151.40^{\mathrm{c}}$ & $544.20^{\mathrm{d}}$ & $219.30^{\mathrm{d}}$ & $121.30^{\mathrm{d}}$ & $183.20^{\mathrm{b}}$ & $324.90^{\mathrm{c}}$ & $799.00^{\mathrm{b}}$ \\
Khaya senegalensis & $976.30^{\mathrm{a}}$ & $139.60^{\mathrm{d}}$ & $486.20^{\mathrm{d}}$ & $211.60^{\mathrm{e}}$ & $121.00^{\mathrm{d}}$ & $182.50^{\mathrm{b}}$ & $274.60^{\mathrm{d}}$ & $368.70^{\mathrm{a}}$ \\
Kigalia Africana $^{\mathrm{a}}$ & $946.30^{\mathrm{c}}$ & $134.02^{\mathrm{e}}$ & $688.10^{\mathrm{a}}$ & $255.20^{\mathrm{a}}$ & $97.00^{\mathrm{e}}$ & $187.20^{\mathrm{a}}$ & $432.90^{\mathrm{a}}$ & $766.70^{\mathrm{d}}$ \\
Leptadenia lancifolia & $958.30^{\mathrm{b}}$ & $163.30^{\mathrm{b}}$ & $433.10^{\mathrm{e}}$ & $243.90^{\mathrm{b}}$ & $152.80^{\mathrm{a}}$ & $131.20^{\mathrm{f}}$ & $189.20^{\mathrm{f}}$ & $782.30^{\mathrm{c}}$ \\
Maerua angolensis & $922.60^{\mathrm{e}}$ & $174.30^{\mathrm{a}}$ & $586.70^{\mathrm{c}}$ & $228.90^{\mathrm{c}}$ & $144.70^{\mathrm{b}}$ & $164.00^{\mathrm{d}}$ & $357.80^{\mathrm{b}}$ & $767.60^{\mathrm{d}}$ \\
Olea hochstteteri & $941.30^{\mathrm{d}}$ & $138.70^{\mathrm{d}}$ & $438.40^{\mathrm{e}}$ & $206.80^{\mathrm{f}}$ & $96.70^{\mathrm{e}}$ & $171.30^{\mathrm{c}}$ & $231.60^{\mathrm{e}}$ & $301.30^{\mathrm{b}}$ \\
Poupartia sirrea & $838.30^{\mathrm{f}}$ & $132.20^{\mathrm{e}}$ & $591.20^{\mathrm{b}}$ & $230.30^{\mathrm{c}}$ & $140.30^{\mathrm{c}}$ & $143.00^{\mathrm{e}}$ & $360.90^{\mathrm{b}}$ & $742.60^{\mathrm{e}}$ \\
\hline MEAN & $\mathbf{9 3 8 . 0 1}$ & $\mathbf{1 4 7 . 6 4}$ & $\mathbf{5 3 8 . 2 7}$ & $\mathbf{2 2 8 . 0 0}$ & $\mathbf{1 2 4 . 8 2}$ & $\mathbf{1 6 6 . 0 6}$ & $\mathbf{3 1 0 . 2 7}$ & $\mathbf{7 8 9 . 7 4}$ \\
SEM & $\mathbf{1 . 4 6}$ & $\mathbf{2 . 0 6}$ & $\mathbf{0 . 9 6}$ & $\mathbf{1 . 3 1}$ & $\mathbf{1 . 0 8}$ & $\mathbf{1 . 3 3}$ & $\mathbf{0 . 9 3}$ & $\mathbf{0 . 4 3}$ \\
\hline
\end{tabular}

$\mathrm{a}, \mathrm{b}, \mathrm{c}, \mathrm{d}=$ mean values along the same column with different superscripts are significantly different $(\mathrm{P}<0.05)$; $\mathrm{DM}=$ Dry Matter; $\mathrm{CP}=\mathrm{Crude}$ protein; $\mathrm{NDF}=\mathrm{Neutral}$ detergent fibre; $\mathrm{ADF}=$ Acid detergent fibre; Acid detergent lignin; ADIash=Acid detergent insoluble ash; Cell.=Cellulose and $\mathrm{HC}=\mathrm{Hemi}$ cellulose; $\mathrm{SEM}=\mathrm{Standard}$ error of means.

Table 2: Anti-nutritional factors of browse forages of semi arid zone of Nigeria (mg/g DM)

\begin{tabular}{lllllllc}
\hline Browse Forages & TCT & PHE & SAP & OXA & PHY & HCN & FLU \\
\hline Garderna sokotensis & $0.12^{\mathrm{c}}$ & $0.41^{\mathrm{c}}$ & $2.95^{\mathrm{a}}$ & $5.01^{\mathrm{c}}$ & $2.43^{\mathrm{de}}$ & 0.06 & 0.0010 \\
Khaya senegalensis & $0.21^{\mathrm{b}}$ & $0.48^{\mathrm{a}}$ & $2.02^{\mathrm{d}}$ & $7.20^{\mathrm{a}}$ & $5.81^{\mathrm{a}}$ & 0.04 & 0.0010 \\
Kigalia Africana & $0.08^{\mathrm{d}}$ & $0.37^{\mathrm{d}}$ & $2.02^{\mathrm{d}}$ & $5.02^{\mathrm{c}}$ & $2.22^{\mathrm{f}}$ & 0.08 & 0.0014 \\
Leptadenia lancifolia & $0.15^{\mathrm{c}}$ & $0.45^{\mathrm{b}}$ & $2.16^{\mathrm{c}}$ & $6.22^{\mathrm{b}}$ & $4.51^{\mathrm{b}}$ & 0.06 & 0.0010 \\
Maerua angolensis & $0.41^{\mathrm{a}}$ & $0.32^{\mathrm{e}}$ & $2.78^{\mathrm{b}}$ & $4.59^{\mathrm{d}}$ & $2.82^{\mathrm{d}}$ & 0.03 & 0.0011 \\
Olea hochstteteri & $0.12^{\mathrm{c}}$ & $0.24^{\mathrm{f}}$ & $2.05^{\mathrm{d}}$ & $8.14^{\mathrm{a}}$ & $2.02^{\mathrm{f}}$ & 0.03 & 0.0010 \\
Poupartia sirrea & $0.14^{\mathrm{c}}$ & $0.31^{\mathrm{e}}$ & $1.08^{\mathrm{e}}$ & $5.10^{\mathrm{c}}$ & $3.97^{\mathrm{c}}$ & 0.03 & 0.0007 \\
\hline MEAN & $\mathbf{0 . 1 8}$ & $\mathbf{0 . 3 7}$ & $\mathbf{2 . 1 5}$ & $\mathbf{5 . 8 9}$ & $\mathbf{3 . 3 9}$ & $\mathbf{0 . 0 5}$ & $\mathbf{0 . 0 0 0 8}$ \\
SEM & $\mathbf{0 . 0 2}$ & $\mathbf{0 . 3 6}$ & $\mathbf{0 . 5 4}$ & $\mathbf{0 . 4 1}$ & $\mathbf{0 . 0 2}$ & $\mathbf{0 . 0 0 7}$ & $\mathbf{0 . 0 0 0 0 6}$ \\
\hline
\end{tabular}

$\mathrm{a}, \mathrm{b}, \mathrm{c}, \mathrm{d}=$ mean values along the same column with different superscripts are significantly different $(\mathrm{P}<0.05)$; TCT=Total condenced tannin; PHE=Phenolics; SAP=Saponin; OXA=Oxalate; PHY=Phytate: HCN=Hydrogen cyanide; FLU; Floroacetate; SEM=Standard error of means. 


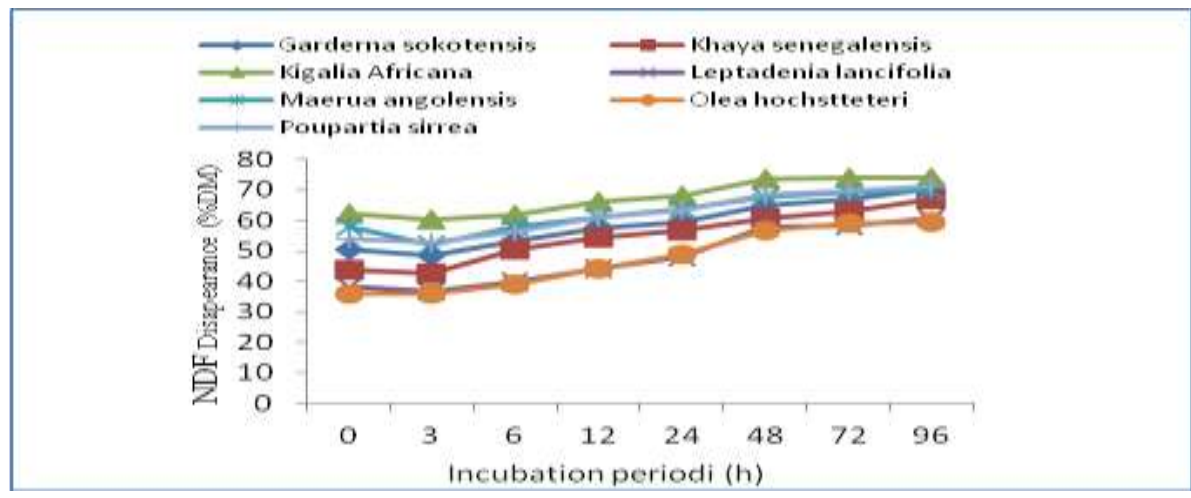

Figure 1. NDF disappearance of the browse forages

Table 3. Degradation characteristics and Effective degradability of NDF of semi arid browse forages incubated in the rumen of bulls

\begin{tabular}{lcccccc}
\hline Browse Forages & $\mathbf{a}$ & $\mathbf{b}$ & $\mathbf{a}+\mathbf{b}$ & $\mathbf{c}$ & $\mathbf{L a g} \mathbf{T}$ & ED \\
\hline Garderna sokotensis & $50.42^{\mathrm{d}}$ & $20.73^{\mathrm{b}}$ & $71.15^{\mathrm{b}}$ & $0.027^{\mathrm{b}}$ & $1.70^{\mathrm{d}}$ & $53.50^{\mathrm{d}}$ \\
Khaya senegalensis & $43.89^{\mathrm{e}}$ & $21.30^{\mathrm{b}}$ & $65.19^{\mathrm{c}}$ & $0.042^{\mathrm{b}}$ & $0.50^{\mathrm{e}}$ & $49.10^{\mathrm{e}}$ \\
Kigalia Africana & $62.20^{\mathrm{a}}$ & $12.86^{\mathrm{d}}$ & $75.06^{\mathrm{a}}$ & $1.035^{\mathrm{a}}$ & $4.10^{\mathrm{b}}$ & $64.00^{\mathrm{a}}$ \\
Leptadenia lancifolia & $38.24^{\mathrm{f}}$ & $24.44^{\mathrm{a}}$ & $62.68^{\mathrm{d}}$ & $0.028^{\mathrm{b}}$ & $2.80^{\mathrm{c}}$ & $41.50^{\mathrm{f}}$ \\
Maerua angolensis & $58.06^{\mathrm{b}}$ & $12.46^{\mathrm{d}}$ & $70.52^{\mathrm{b}}$ & $0.034^{\mathrm{b}}$ & $6.80^{\mathrm{a}}$ & $59.30^{\mathrm{b}}$ \\
Olea hochstteteri & $35.93^{\mathrm{g}}$ & $24.91^{\mathrm{a}}$ & $60.84^{\mathrm{e}}$ & $0.035^{\mathrm{b}}$ & $1.50^{\mathrm{d}}$ & $40.60^{\mathrm{f}}$ \\
Poupartia sirrea & $53.98^{\mathrm{c}}$ & $17.24^{\mathrm{c}}$ & $71.22^{\mathrm{b}}$ & $0.038^{\mathrm{b}}$ & $1.70^{\mathrm{d}}$ & $57.30^{\mathrm{c}}$ \\
\hline MEAN & $\mathbf{4 8 . 9 6}$ & $\mathbf{1 9 . 1 3}$ & $\mathbf{6 8 . 0 9}$ & $\mathbf{0 . 1 8}$ & $\mathbf{2 . 7 2}$ & $\mathbf{5 2 . 1 9}$ \\
SEM & $\mathbf{0 . 4 2}$ & $\mathbf{1 . 0 2}$ & $\mathbf{1 . 2 3}$ & $\mathbf{0 . 3 7}$ & $\mathbf{0 . 5 2}$ & $\mathbf{1 . 3 2}$ \\
\hline
\end{tabular}

$\mathrm{a}, \mathrm{b}, \mathrm{c}$, means in the same column with different superscript differ significantly $(\mathrm{P}<0.05) ; \mathrm{SEM}=$ Standard error means; NS=Not Significant

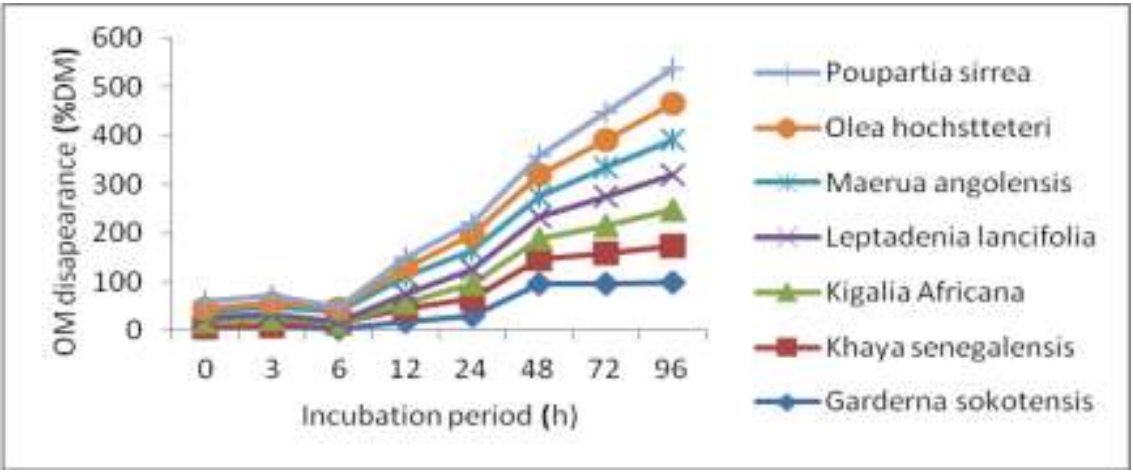

Figure 2. OM disappearance of selected browse forages

Table 4. Degradation characteristics and Effective degradability of OM of semi arid browse forages incubated in the rumen of bulls

\begin{tabular}{lllllll}
\hline \multicolumn{1}{c}{ Browse Forages } & $\mathbf{a}$ & $\mathbf{b}$ & $\mathbf{a + b}$ & $\mathbf{c}$ & Lag T $^{\mathrm{b}}$ & ED \\
\hline Garderna sokotensis & $18.76^{\mathrm{a}}$ & $63.30^{\mathrm{d}}$ & $72.06^{\mathrm{b}}$ & 0.030 & $0.50^{\mathrm{c}}$ & $20.70^{\mathrm{a}}$ \\
Khaya senegalensis & $8.33^{\mathrm{b}}$ & $68.01^{\mathrm{b}}$ & $76.34^{\mathrm{a}}$ & 0.023 & $2.00^{\mathrm{b}}$ & $19.80^{\mathrm{a}}$ \\
Kigalia Africana & $4.19^{\mathrm{d}}$ & $67.69^{\mathrm{c}}$ & $72.60^{\mathrm{b}}$ & 0.025 & $2.00^{\mathrm{b}}$ & $17.10^{\mathrm{b}}$ \\
Leptadenia lancifolia & $6.26^{\mathrm{c}}$ & $61.20^{\mathrm{e}}$ & $67.46^{\mathrm{c}}$ & 0.033 & $2.00^{\mathrm{b}}$ & $19.90^{\mathrm{a}}$ \\
Maerua angolensis & $2.23^{\mathrm{f}}$ & $59.24^{\mathrm{f}}$ & $61.47^{\mathrm{d}}$ & 0.060 & $0.90^{\mathrm{c}}$ & $20.00^{\mathrm{a}}$ \\
Olea hochstteteri & $4.22^{\mathrm{d}}$ & $67.28^{\mathrm{c}}$ & $71.50^{\mathrm{b}}$ & 0.026 & $3.00^{\mathrm{a}}$ & $16.80^{\mathrm{b}}$ \\
Poupartia sirrea & $3.24^{\mathrm{e}}$ & $73.16^{\mathrm{a}}$ & $76.40^{\mathrm{a}}$ & 0.017 & $0.40^{\mathrm{c}}$ & $12.30^{\mathrm{c}}$ \\
\hline MEAN & $\mathbf{6 . 7 5}$ & $\mathbf{6 5 . 6 9}$ & $\mathbf{7 1 . 1 2}$ & $\mathbf{0 . 0 3}$ & $\mathbf{1 . 5 4}$ & $\mathbf{1 8 . 0 9}$ \\
SEM & $\mathbf{0 . 6 7}$ & $\mathbf{0 . 3 8}$ & $\mathbf{0 . 9 3}$ & $\mathbf{0 . 0 0 7}$ & $\mathbf{0 . 6 1}$ & $\mathbf{1 . 0 6}$ \\
\hline
\end{tabular}

$a, b, c$, means in the same column with different superscript differ significantly $(\mathrm{P}<0.05)$; SEM=Standard error means; NS=Not Significant 